\title{
Relationship Between Medication Adherence and Health-Related Quality of Life in Subjects With COPD: A Systematic Review
}

\author{
Tamás Ágh MD PhD, Péterné Dömötör MSc, Zoltán Bártfai MD PhD, \\ András Inotai PharmD PhD, Eszter Fujsz MD, and Ágnes Mészáros PharmD PhD \\ Introduction \\ Methods \\ Literature Search and Eligibility Criteria \\ Quality Assessment of the Included Studies \\ Results \\ Search Results \\ Methodological Quality \\ Medication Adherence and HRQOL \\ Discussion \\ Association Between Medication Adherence and HRQOL \\ Future Studies and Recommendations \\ Limitations \\ Conclusions
}

BACKGROUND: Various aspects of medication adherence and health-related quality of life (HRQOL) have been studied in subjects with COPD. Nevertheless, little is known about the association between these factors. The aim of this study was to undertake a systematic review of the published literature focusing on the relationship between medication adherence and HRQOL in COPD. METHODS: A systematic literature search of English language articles was conducted in April 2013 using MEDLINE. No publication date limits were defined. All of the included studies were assessed for quality. RESULTS: Seven studies were included in the review. Three of the assessed studies found no correlation, and 3 studies described positive and 2 studies reported negative associations between medication adherence and HRQOL. The results indicate that an improved HRQOL may be a trigger for non-adherence in patients with COPD. CONCLUSIONS: The relationship between medication adherence and HRQOL may be dual. The effect of medication adherence on HRQOL might be a consequence of the effectiveness of therapy and the negative effects (ie, side effects, daily life limitation of therapy, social stigma) that it can generate. HRQOL might also influence the patterns of patients' drug use, as an increased HRQOL might trigger non-adherence. The dynamics between adherence and HRQOL might differ over time, as the negative effects of medication non-adherence might become dominant in the long term. Key words: chronic obstructive pulmonary disease; COPD; medication adherence; medication compliance; quality of life; patient outcome assessment; respiratory therapy. [Respir Care 2015;60(2):297-303. @ 2015 Daedalus Enterprises]

Drs Ágh and Inotai are affiliated with the Syreon Research Institute, Budapest, Hungary. Ms Dömötör and Drs Bártfai and Fujsz are affiliated with the Department of Pulmonology, Elisabeth Teaching Hospital and Rehabilitation Institute Sopron, Sopron, Hungary. Ms Dömötör is also affiliated with the Faculty of Economics, University of West Hungary, Sopron, Hungary. Dr Mészáros is affiliated with the University Pharmacy Department of Pharmacy Administration, Semmelweis University, Budapest, Hungary.

Supplementary material related to this paper is available at http:// www.rcjournal.com.
Dr Ágh and Ms Dömötör are co-first authors.

The authors have disclosed no conflicts of interest

Correspondence: Tamás Ágh MD PhD, Syreon Research Institute, Thököly Street 119, 1146 Budapest, Hungary. E-mail: tamas.agh@ syreon.eu.

DOI: $10.4187 /$ respcare. 03123 


\section{Medication Adherence and HRQOL in Subjects With COPD}

\section{Introduction}

COPD is a major public health problem. ${ }^{1,2}$ The prevalence of COPD is increasing worldwide, resulting in a substantial economic burden. ${ }^{3}$

Medication adherence "refers to the act of conforming to the recommendations made by the provider with respect of timing, dosage and frequency of medication taking." 4 Medication non-adherence is common in COPD. ${ }^{5}$ Nonadherence reduces the clinical benefit of the therapy and accounts for many of the observed differences between the efficacy reported in randomized controlled trials (RCTs) and the effectiveness of the drug treatment achieved in real-world conditions. In RCTs, conditions are highly controlled, and the stringent follow-up protocol limits the occurrence of medication non-adherence; therefore, non-adherence rates derived from RCTs do not reflect an objective picture of medication adherence. Although the average rates of adherence to COPD medication in RCTs have been estimated to be $\sim 70-90 \%$, in real-world conditions, these rates are only in the range of $20-60 \% .^{5}$ The discontinuation of COPD therapy contributes to the increased frequency of exacerbations, number of hospitalizations, and mortality rate. ${ }^{6-8}$

COPD impairs the health-related quality of life (HRQOL) markedly; patients experience substantial limitations in their daily life. ${ }^{9}$ HRQOL, one of the most important patient-reported outcomes, truly reflects the individual's selfreport on health status and well-being. ${ }^{10}$

Medication adherence and HRQOL are 2 important indicators in determining the success of drug treatments. Although adherence and HRQOL have been studied intensively in COPD, less is known about the association between these factors.

The aim of this research was to undertake a systematic review of the published literature to gain a better understanding of the relationship between medication adherence and HRQOL in patients with COPD. Our hypothesis was that the association between medication adherence and HRQOL is dual. Therefore, the objective of this study was to evaluate not only the effect of medication adherence on HRQOL but also the impact of HRQOL on medication adherence. To our knowledge, no comprehensive review has been published on this topic to date.

\section{Methods}

\section{Literature Search and Eligibility Criteria}

A systematic literature search was conducted in April 2013 using MEDLINE (via PubMed) with the following search string: (compliance OR adherence OR persistence OR non-compliance OR non-adherence OR non-persistence OR noncompliance OR nonadherence OR nonper- sistence OR treatment acceptance OR concordance) AND quality of life AND (chronic obstructive pulmonary disease OR COPD). No publication date limits were defined.

The search results were considered in 2 steps. Initially, the titles and abstracts of all articles were screened; those deemed relevant were analyzed in full. Additionally, the references of the relevant articles were screened for additional eligible studies. The literature screening was conducted by 2 independent reviewers (TA and PD). No major disagreements between the reviewers occurred.

The reasons for exclusion in both steps were (1) the article was not written in English; (2) the article was not published in a peer-reviewed journal; (3) the article was an editorial, letter, case report, or review; (4) the article was not related to COPD; (5) the article was related to oxygen therapy; (6) the article had not evaluated the association between medication adherence/compliance/persistence and HRQOL in COPD; or (6) the article had not reported the results of studies conducted in real-world settings.

The data extraction focused on and was limited to findings relevant to the research topic. The following information was extracted from each study: (1) the first author and year of publication, (2) the country, (3) the study design, (4) the study population characteristics (size, percent male, mean age, percent-of-predicted $\mathrm{FEV}_{1}$, COPD stage), (5) the medication therapy, (6) the method of measuring and defining adherence, (7) the method of measuring HRQOL, (8) the evaluated association between medication adherence and HRQOL, (9) the statistical method(s) used, and (10) the results.

\section{Quality Assessment of the Included Studies}

For quality assessment of the included studies, the Strengthening the Reporting of Observational Studies in Epidemiology (STROBE) checklist for cohort, case control, and cross-sectional studies was used. ${ }^{11}$ All studies were independently assessed by TA and PD; disagreements were resolved by ÁM. The results for each study were summarized as the percentage of the fulfilled criteria. The criteria that were not applicable to a study were excluded from the quality assessment.

\section{Results}

\section{Search Results}

The database search resulted in 245 hits. The screening of the titles and abstracts identified 21 potentially eligible articles. After reviewing the relevant full texts, 7 studies were finally included in the systematic review. No additional record was identified through a manual search of the references of the relevant articles. Figure 1 shows the break- 


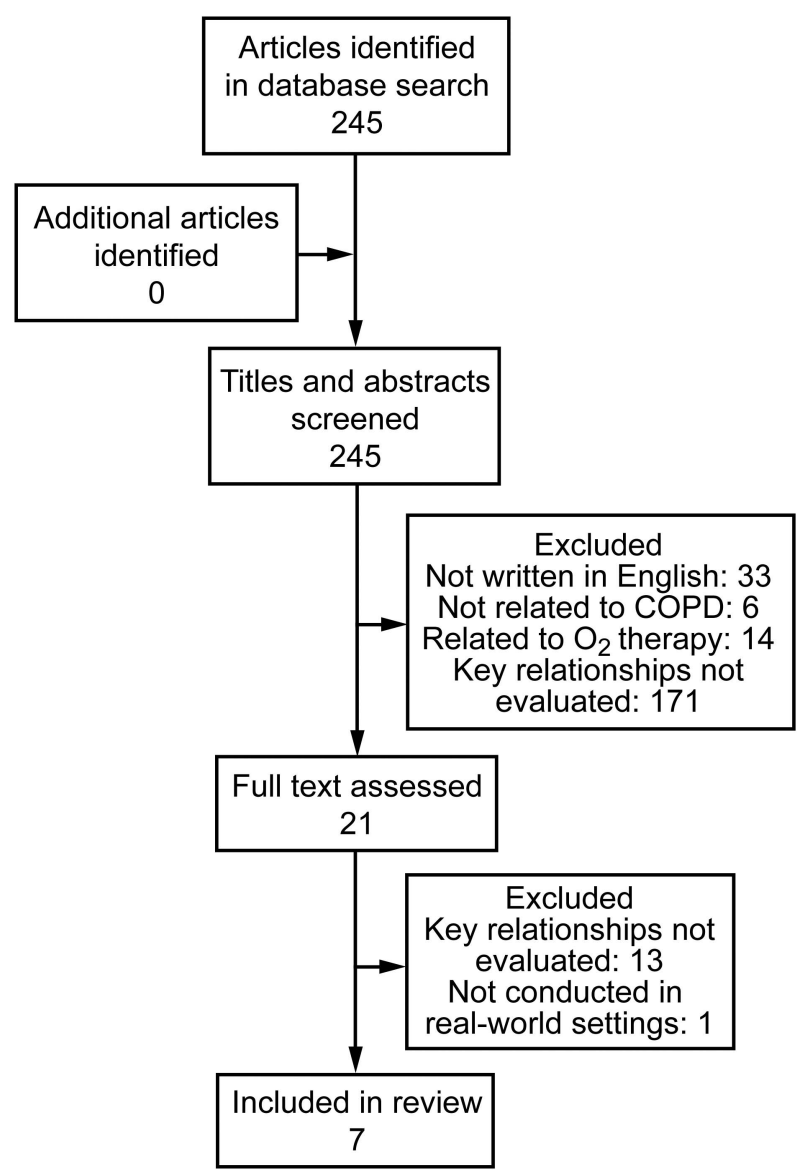

Fig. 1. Flow diagram of the systematic literature search.

down of when and for what reason records were excluded from the review.

Five studies were prospective cohort studies, ${ }^{12-16}$ and 2 cross-sectional studies ${ }^{17,18}$ were also included. The earliest study dated from $1995,{ }^{16}$ and the most recent was published in 2013.15 The included studies originated from Canada and the United Sates, ${ }^{16}$ Hungary, ${ }^{17}$ Japan, ${ }^{15,18}$ The Netherlands, ${ }^{14}$ and the United Kingdom. ${ }^{12,13}$ The population size varied between $11^{12}$ and $985^{16}$ subjects, with a mean age of $58^{14}$ to $76^{15} \mathrm{y}$. The general characteristics of the reviewed studies are presented in Table 1.

\section{Methodological Quality}

The included studies fulfilled the STROBE criteria between $64 \%{ }^{14}$ and $81 \% .{ }^{16}$ Details of the quality assessment are provided (see the supplementary materials at http:// www.rcjournal.com). The majority of the studies described their scope, study design, settings, participants, variables, and measurements adequately. Hesselink et al ${ }^{14}$ were the only authors who did not clearly define the method for measuring adherence. No study provided information on missing data and how they dealt with. All of the reviewed studies described their statistical methods in detail; however, there was only one study that undertook a sensitivity analysis to examine the robustness of the results. ${ }^{16}$

\section{Medication Adherence and HRQOL}

Medication adherence was measured in all included studies, but none of these assessed persistence. Medication adherence was analyzed by a self-reported questionnaire, ${ }^{12,14,16-18}$ counting the number of unused doses of medication, ${ }^{15}$ or an electronic monitoring method. ${ }^{12,13,16}$ Turner et al ${ }^{16}$ and Bosley et al ${ }^{12}$ used a self-reported questionnaire and electronic monitoring for measuring adherence simultaneously, but both groups considered the subjects to be adherent based on the results of the electronic monitoring only. Except for the studies conducted by Mochizuki et al ${ }^{15}$ and Bosley et al, ${ }^{12}$ most studies defined adherence as a dichotomous variable.

The questionnaires used to measure HRQOL differed between the studies. In most studies, a disease-specific instrument was used ${ }^{12-15,18}$; only 2 studies measured generic HRQOL. ${ }^{16,17}$ The disease-specific St George Respiratory Questionnaire was the most commonly used quality-of-life instrument. ${ }^{12,13,15,18}$

The association between adherence and HRQOL was evaluated in all included studies; however, only one study explored the effect of medication adherence on HRQOL, ${ }^{12}$ and one explored the impact of HRQOL on adherence. ${ }^{17}$ Detailed information on the measurements of adherence and HRQOL, the applied statistical methods, and the results on the association between adherence and HRQOL are summarized in Table 2 .

\section{Discussion}

A comprehensive review of the relationship between medication adherence and HRQOL in patients with COPD was missing from the literature. Only 7 relevant articles were found through our systematic literature search. The findings of the reviewed studies were heterogeneous; nevertheless, some demonstrated that the relationship between medication adherence and HRQOL may be dual and may be affected by multiple factors.

\section{Association Between Medication Adherence and HRQOL}

The evidence suggests that, in COPD, non-adherence to medication may not have a clear negative impact on HRQOL. Three studies ${ }^{14-16}$ found no correlation, whereas 3 studies $^{12,13,18}$ described positive and 2 studies ${ }^{16,17}$ reported negative associations between adherence and HRQOL. This heterogeneity might be caused by several factors, such as differences in study design, study popu- 


\section{Medication Adherence and HRQOL in Subjects With COPD}

Table 1. Characteristics of the Included Studies

\begin{tabular}{|c|c|c|c|c|}
\hline Reference & Country & $\begin{array}{l}\text { Study Design } \\
\text { (Follow-Up) }\end{array}$ & Study Population Characteristics & Medication Therapy \\
\hline Ágh et $\mathrm{al}^{17}$ & Hungary & Cross-sectional study & $\begin{array}{l}n=170 ; \text { mean age, } 64 \mathrm{y} ; 42 \% \text { male; } \\
\mathrm{FEV}_{1}, 64 \% \text { of predicted; GOLD } \\
\text { stages I/II/III/IV, 23/52/21/4\% }\end{array}$ & $\begin{array}{l}\text { Short-acting and long-acting } \beta \text { agonists, } \\
\text { short-acting and long-acting } \\
\text { anticholinergics, inhaled } \\
\text { corticosteroids, theophylline, } \\
\text { combinations }\end{array}$ \\
\hline $\begin{array}{l}\text { Bosley } \\
\text { et } \mathrm{al}^{12}\end{array}$ & United Kingdom & $\begin{array}{l}\text { Prospective cohort } \\
\text { (4 wk) }\end{array}$ & $\begin{array}{l}n=11 ; \text { mean age, } 64 \mathrm{y} ; 36 \% \text { male; } \\
\mathrm{FEV}_{1} \% \text { of predicted, ND; GOLD } \\
\text { stages I/II/III/IV, ND. }\end{array}$ & Bronchodilators (all by nebulizer) \\
\hline $\begin{array}{l}\text { Corden } \\
\text { et }^{113}\end{array}$ & United Kingdom & $\begin{array}{l}\text { Prospective cohort } \\
\quad(4 \mathrm{wk})\end{array}$ & $\begin{array}{l}n=82 ; \text { mean age, } 65 \mathrm{y} ; 54 \% \text { male; } \\
\text { FEV }_{1} \% \text { of predicted, ND; GOLD } \\
\text { stages } \mathrm{I} / \mathrm{II} / \mathrm{III} / \mathrm{IV}, \mathrm{ND}\end{array}$ & $\begin{array}{l}\text { Short-acting and long-acting } \beta \text { agonists, } \\
\text { short-acting anticholinergics, } \\
\text { corticosteroids (all by nebulizer) }\end{array}$ \\
\hline $\begin{array}{l}\text { Hesselink } \\
\text { et al }^{14}\end{array}$ & The Netherlands & $\begin{array}{l}\text { Prospective cohort } \\
\quad(2 \mathrm{y})\end{array}$ & $\begin{array}{l}n=120(\mathrm{COPD}) ; \text { mean age, } 58 \mathrm{y} ; \\
58 \% \text { male; } \mathrm{FEV}_{1}, 61 \% \text { of } \\
\text { predicted; GOLD stages I/II/III/IV, } \\
\text { ND }\end{array}$ & Anti-inflammatory agents \\
\hline $\begin{array}{l}\text { Mochizuki } \\
\text { et al }{ }^{15}\end{array}$ & Japan & $\begin{array}{l}\text { Prospective cohort } \\
\quad(12 \mathrm{wk})\end{array}$ & $\begin{array}{l}n=44 ; \text { mean age, } 76 \text { y; } 73 \% \text { male; } \\
\text { FEV }_{1}, 55 \% \text { of predicted; GOLD } \\
\text { stages I/IIIIII/IV } 0 / 64 / 36 / 0 \%\end{array}$ & $\begin{array}{l}\text { Transdermal tulobuterol patch, inhaled } \\
\text { salmeterol }\end{array}$ \\
\hline $\begin{array}{l}\text { Takemura } \\
\text { et }^{118}\end{array}$ & Japan & Cross-sectional study & $\begin{array}{c}n=55 ; \text { mean age, } 69 \mathrm{y} ; 73 \% \text { male; } \\
\mathrm{FEV}_{1}, 68 \% \text { of predicted; GOLD } \\
\text { stages } \mathrm{I} / \mathrm{II} / \mathrm{III} / \mathrm{IV}, 24 / 54 / 16 / 1 \%\end{array}$ & $\begin{array}{l}\text { Long-acting muscarinic antagonists, } \\
\text { short-acting and long-acting } \beta \\
\text { agonists, inhaled corticosteroids }\end{array}$ \\
\hline $\begin{array}{l}\text { Turner } \\
\text { et al }^{16}\end{array}$ & $\begin{array}{l}\text { Canada, } \\
\text { United States }\end{array}$ & $\begin{array}{l}\text { Prospective cohort } \\
\quad(1 \mathrm{y})\end{array}$ & $\begin{array}{l}n=985 ; \text { mean age, } 61 \mathrm{y} ; 81 \% \text { male; } \\
\text { FEV }_{1}, 41 \% \text { of predicted; GOLD } \\
\text { stages I/II/III/IV, ND }\end{array}$ & Bronchodilators (all by nebulizer) \\
\hline
\end{tabular}

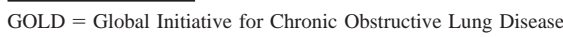

$\mathrm{ND}=$ not determined

lation, therapy, adherence measurement methods, and HRQOL instruments.

Considering the fact that the different HRQOL questionnaires may assess different aspects of HRQOL, the type of HRQOL questionnaire could significantly influence the association between adherence and HRQOL. In the study conducted by Turner et al, ${ }^{16} 3$ different HRQOL instruments were used: the Sickness Impact Profile measured the effect of illness on daily functioning, the Profile of Mood States measured feelings and mood, and the Recent Life Changes Questionnaire measured changes in lifestyle. Turner et $\mathrm{al}^{16}$ found no correlation between adherence and HRQOL measured by the Sickness Impact Profile and Profile of Mood States; however, the non-adherent subjects reported significantly higher HRQOL scores on the Recent Life Changes Questionnaire. The number of the included studies was limited, and the types of HRQOL questionnaires were very heterogeneous in these; therefore, HRQOL could be used only in a broad sense to interpret the association between medication adherence and HRQOL. In this broad concept, HRQOL has been defined as the patient's subjective perception of the impact of the disease and its treatment(s) on daily life, physical/psychological/social functioning, and well-being. ${ }^{19}$
The effect of medication adherence on HRQOL can be derived from the effectiveness of the pharmacologic therapy and the negative effects that it can generate. Medication adherence improves a patient's HRQOL by reducing the symptoms, disease progression, and frequency and severity of exacerbations. Aside from the treatment-related side effects, there might be other factors as well by which adherence could impair a patient's HRQOL, such as a daily life limitation of therapy and the social stigma of using inhalers in public. Patients with moderate-to-severe COPD are generally treated with combination therapy, and most respiratory medications are dosed several times daily. Therefore, COPD treatment regimens might significantly impact a patient's daily life. ${ }^{17}$ Patients with COPD are mostly treated with inhalation medication; however, the perceived social stigma associated with using inhalers in public might also affect HRQOL. ${ }^{20}$

Not only can adherence affect HRQOL, but HRQOL may also impact medication adherence. ${ }^{21}$ Ágh et al ${ }^{17}$ found that an improved HRQOL was a trigger for non-adherence in subjects with COPD. They suggested that a patient's decision to adhere and to what extent is a personal tradeoff between the benefits and negative effects of the therapy at any given time, which is consistent with the view of 


\section{Medication Adherence and HRQOL in Subjects With COPD}

Table 2. Association of Medication Adherence and HRQOL Based on the Results of the Included Studies

\begin{tabular}{|c|c|c|c|c|c|c|c|}
\hline & Ágh et al ${ }^{17}$ & Bosley et al ${ }^{12}$ & Corden et al ${ }^{13}$ & Hesselink et al ${ }^{14}$ & Mochizuki et al ${ }^{15}$ & Takemura et al ${ }^{18}$ & Turner et a ${ }^{16}$ \\
\hline \multicolumn{8}{|l|}{ Adherence } \\
\hline Measurement & $\begin{array}{l}\text { Self-reported } \\
\text { questionnaire } \\
\text { (MMAS-4) }\end{array}$ & $\begin{array}{l}\text { Electronic monitoring, } \\
\text { self-reported } \\
\text { questionnaire }\end{array}$ & Electronic monitoring & $\begin{array}{l}\text { Self-reported } \\
\text { questionnaire }\end{array}$ & $\begin{array}{l}\text { Counting number } \\
\text { of unused } \\
\text { doses of } \\
\text { medication }\end{array}$ & $\begin{array}{l}\text { Self-reported } \\
\text { questionnaire }\end{array}$ & $\begin{array}{l}\text { Electronic monitoring, } \\
\text { self-reported } \\
\text { questionnaire }\end{array}$ \\
\hline Variable & Dichotomous & $\begin{array}{l}\text { Dichotomous, } \\
\text { continuous }\end{array}$ & Dichotomous & Dichotomous & Continuous & Dichotomous & Dichotomous \\
\hline $\begin{array}{l}\text { Threshold of } \\
\text { adherence }\end{array}$ & $\geq 3$ scores & $\begin{array}{l}\text { Subjects on regimens } \\
\text { of up to } 4 \text { times } \\
\text { daily, taking } \\
\geq 70 \% \text { of } \\
\text { treatment; subjects } \\
\text { on regimens of up } \\
\text { to } 5 \text { times daily, } \\
\text { taking } \geq 60 \% \text { of } \\
\text { treatment }\end{array}$ & $\begin{array}{c}\text { Taking } \geq 70 \% \text { of } \\
\text { treatment }\end{array}$ & Not reported & Not applicable & $\geq 4$ scores & $\geq \underset{\text { use } / \mathrm{d}}{25 \mathrm{~min}}$ of nebulizer \\
\hline $\begin{array}{l}\text { HRQOL } \\
\text { Evaluated } \\
\quad \text { association }\end{array}$ & EQ-5D-3L & SGRQ & SGRQ & QOL-RIO & SGRQ & SGRQ & SIP, POMS, RLCQ \\
\hline $\begin{array}{c}\text { Adherence } \leftrightarrow \\
\text { HRQOL }\end{array}$ & Yes & Yes & Yes & Yes & Yes & Yes & Yes \\
\hline $\begin{array}{c}\text { Adherence } \rightarrow \\
\text { HRQOL }\end{array}$ & No & Yes & No & No & No & No & No \\
\hline $\begin{array}{l}\mathrm{HRQOL} \rightarrow \\
\text { adherence }\end{array}$ & Yes & No & No & No & No & No & No \\
\hline $\begin{array}{l}\text { Statistical } \\
\text { methods }\end{array}$ & $\begin{array}{l}\text { Univariate and } \\
\text { multivariate analyses }\end{array}$ & $\begin{array}{l}\text { Univariate and } \\
\text { multivariate } \\
\text { analyses }\end{array}$ & Univariate analysis & $\begin{array}{r}\text { Univariate } \\
\text { analysis }\end{array}$ & $\begin{array}{r}\text { Univariate } \\
\text { analysis }\end{array}$ & $\begin{array}{r}\text { Univariate } \\
\text { analysis }\end{array}$ & Univariate analysis \\
\hline Results & $\begin{array}{l}\text { (1) HRQOL negatively } \\
\text { correlated with } \\
\text { adherence (EQ-5D- } \\
\text { 3L index scores). (2) } \\
\text { Multiple regression } \\
\text { analysis indicated } \\
\text { that an improved } \\
\text { HRQOL had a } \\
\text { significant negative } \\
\text { effect on adherence } \\
\text { (EQ-5D-3L index } \\
\text { scores). }\end{array}$ & $\begin{array}{l}\text { Baseline: No } \\
\text { correlation existed } \\
\text { between \% } \\
\text { adherence and } \\
\text { HRQOL (SGRQ). } \\
\text { At the 4-wk visit: } \\
\text { (1) Percent } \\
\text { adherence } \\
\text { correlated with an } \\
\text { improved HRQOL } \\
\text { (symptoms, impact, } \\
\text { and total SGRQ } \\
\text { scores). } \\
\text { (2) Multiple } \\
\text { regression analysis } \\
\text { indicated that \% } \\
\text { adherence had a } \\
\text { significant positive } \\
\text { effect on HRQOL } \\
\text { (total SGRQ } \\
\text { scores). }\end{array}$ & $\begin{array}{l}\text { Baseline: No } \\
\text { correlation existed } \\
\text { between adherence } \\
\text { and HRQOL } \\
\text { (SGRQ). } \\
\text { At the 4-wk visit: } \\
\text { Adherence } \\
\text { correlated with an } \\
\text { improved HRQOL } \\
\text { (symptoms, impact, } \\
\text { and total SGRQ } \\
\text { scores). }\end{array}$ & $\begin{array}{l}\text { During the 2-y } \\
\text { follow-up: No } \\
\text { significant } \\
\text { correlation } \\
\text { existed } \\
\text { between } \\
\text { adherence and } \\
\text { HRQOL } \\
\text { (QOL-RIO } \\
\text { scores). }\end{array}$ & $\begin{array}{l}\text { After the 12-wk } \\
\text { follow-up } \\
\text { period: No } \\
\text { significant } \\
\text { correlation } \\
\text { existed } \\
\text { between \% } \\
\text { adherence (to } \\
\text { either } \\
\text { medication) } \\
\text { and HRQOL } \\
\text { (SGRQ total } \\
\text { scores). }\end{array}$ & $\begin{array}{l}\text { Mean adherence } \\
\text { score showed } \\
\text { significant } \\
\text { correlation } \\
\text { with an } \\
\text { improved } \\
\text { HRQOL } \\
\text { (total SGRQ } \\
\text { scores and } \\
\text { subscores } \\
\text { expected for } \\
\text { activities). }\end{array}$ & $\begin{array}{l}\text { No correlation existed } \\
\text { between adherence } \\
\text { and HRQOL } \\
\text { measured with } \\
\text { POMS and SIP. A } \\
\text { significant negative } \\
\text { correlation existed } \\
\text { between adherence } \\
\text { and HRQOL } \\
\text { measured with } \\
\text { RLCQ. }\end{array}$ \\
\hline $\begin{array}{l}\text { HRQOL }=\text { health-rel } \\
\text { MMAS } 4=4 \text {-Item N } \\
\text { SGRQ = St George } \\
\text { QOL-RIO = Quality } \\
\text { SIP = Sickness Impa } \\
\text { POMS = Profile of } \\
\text { RLCQ = Recent Life } \\
\text { Adherence } \leftrightarrow \text { HRQOI } \\
\text { Adherence } \rightarrow \text { HRQO } \\
\text { HRQOL } \rightarrow \text { adherence }\end{array}$ & $\begin{array}{l}\text { ted quality of life } \\
\text { lorisky Medication Adherence } \\
\text { espiratory Questionnaire } \\
\text { of Life in Respiratory Illness } \\
\text { t Profile } \\
\text { Iood States } \\
\text { Changes Questionnaire } \\
=\text { correlation between medic } \\
=\text { effect of medication adher } \\
=\text { effect of HRQOL on medi }\end{array}$ & $\begin{array}{l}\text { ation adherence and HRQOL } \\
\text { rence on HRQOL } \\
\text { ication adherence }\end{array}$ & & & & & \\
\hline
\end{tabular}

Bosley et $\mathrm{al}^{12}$ that adherence is related to the current health status of the patient and is not dependent on previous experience of illness. The initiation of a pharmacologic therapy in newly diagnosed COPD patients might significantly improve their HRQOL; however, later, this HRQOL improvement due to medical treatment might be smaller and could be detected only in the long term. ${ }^{22}$ Therefore, if patients have previously been treated for longer durations, the benefits from medication non-adherence might temporarily outweigh the effects of the disease deterioration in the short term. The dynamics between adherence and HRQOL might differ over time. The negative effects of a patient's non-adherence could become more and more significant over a longer time horizon.

Psychiatric disorders such as depression and anxiety are highly prevalent in patients with COPD. ${ }^{23}$ Psychiatric comorbidities influence the relationship between medication adherence and HRQOL. Evidence suggests that depression 


\section{Medication Adherence and HRQOL in Subjects With COPD}

is linked to non-adherence and HRQOL impairment. ${ }^{12,24}$ Therefore, a patient's psychiatric comorbidity might affect the relationship between these factors.

\section{Future Studies and Recommendations}

Overall, the methodology of the reviewed studies was not entirely appropriate to evaluate the relationship between adherence and HRQOL in COPD patients; therefore, it would be important to develop recommendations for future studies in this area.

In the long term, evidence from real-world settings could provide more reliable data regarding the association between medication adherence and HRQOL compared with RCTs. Real-world studies assess effectiveness in unselected populations; subjects are under routine care, taking open-label treatment, with no additional visits, allowing an objective assessment of medication adherence. A study in real-word settings, preferably with a minimum of a 1-y study period and regular screening visits (eg, quarterly), would be desirable.

There are a number of ways to measure adherence; nevertheless, there is no accepted standard because each method has its strengths and limitations. ${ }^{5}$ The easiest way to assess adherence is to collect information from the subjects themselves through questionnaires. However, self-reporting methods might overestimate adherence. The retrospective analysis of prescription refill data is rapid and inexpensive but does not provide information on medication intake or inhaler use directly. Pill counting and canister weighing are widely used methods of adherence assessment, especially in clinical trials; pill counting is limited to oral medications, but canister weighing can be used for inhalers as well. These approaches assess only the quantity of the medication removed from the canister without any indication of ingestion or inhalation. Electronic monitoring methods for measuring adherence can provide more objective data about medication use than the aforementioned methods. Pill bottles, inhalers, and nebulizers can all be fitted with electronic recording devices. The evidence suggests that although the underuse of medications seems to be one of the largest problems in the management of COPD, overuse is also common. ${ }^{5}$ To be able to separate and identify both types of medication non-adherence, it would be of great value to define adherence as a categorical variable (ie, full adherer, partial adherer, partial non-adherer, overuser) or a continuous variable instead of as a dichotomous variable (adherent vs non-adherent).

Regarding the assessment of HRQOL, generic and disease-specific instruments may capture complementary information. Disease-specific instruments seem to be more sensitive for the clinical measures of COPD. However, generic questionnaires capture more broad aspects of health but are less sensitive to clinical changes. ${ }^{25}$ For this reason, the optimal situation would be for generic (eg, EQ-5D health questionnaire) and disease-specific (eg, St George Respiratory Questionnaire) measures to be used simultaneously to monitor a patient's HRQOL.

To understand fully the dynamics of adherence and HRQOL, it would be important to also assess how other factors such as disease symptoms, disease severity, side effects, and the patient's satisfaction (understanding the social and psychological impact of medical therapy) and psychological status (eg, depressive symptoms, anxiety) influence the nature of their relationship. The evidence suggests that there is only a weak correlation between lung function and HRQOL. ${ }^{26}$ As recommended by the Global Initiative for Chronic Obstructive Lung Disease (http:// www.goldcopd.org/uploads/users/files/GOLD_Report_2013 Feb13.pdf, Accessed October 1, 2013), the assessment of disease severity should be based not only on a spirometric assessment but also on the patient-reported outcome instruments (eg, breathlessness measurement using the Modified British Medical Research Council Questionnaire, COPD Assessment Test, Clinical COPD Questionnaire, and Borg scale).

A univariate statistical analysis is important but not sufficient for evaluating the association between medication adherence and HRQOL. Therefore, a univariate analysis needs to be complemented with a multivariate analysis.

\section{Limitations}

Our findings should be considered in light of the following limitations. Our systematic review identified only studies published in English and in peer-reviewed journals, and our search was limited to MEDLINE. We included studies that evaluated the relationship between medication adherence and HRQOL. However, we acknowledge the importance of oxygen therapy and other non-pharmacologic interventions in COPD, such as physical activity, nutrition, and other lifestyle recommendations. The association between adherence to these interventions and HRQOL would also require evaluation.

\section{Conclusions}

The association between medication adherence and HRQOL may be dual. The effect of medication adherence on HRQOL might be a consequence of the effectiveness of the therapy and the negative effects (ie, side effects, daily life limitation of therapy, social stigma) that it can generate. In contrast, the level of HRQOL, may also influence the patterns of patients' drug use; an increased HRQOL may trigger non-adherence. In addition, the dynamics between adherence and HRQOL might differ over time. In the short term, the benefits could be dominant, whereas in the long term, the negative effects of medication nonadherence might become dominant. There is a clear need 


\section{Medication Adherence and HRQOL in Subjects With COPD}

for rigorous research to better understand the dynamics between adherence and HRQOL in COPD. Such data would be critically important for optimal COPD management and should also be considered when integrating medication adherence into health-economic evaluations (eg, adherence interventions).

\section{REFERENCES}

1. Viegi G, Scognamiglio A, Baldacci S, Pistelli F, Carrozzi L. Epidemiology of chronic obstructive pulmonary disease (COPD). Respiration 2001;68(1):4-19.

2. Mannino DM. Chronic obstructive pulmonary disease: definition and epidemiology. Respir Care 2003;48(12):1185-1191; discussion 1191-1193.

3. Chapman KR, Mannino DM, Soriano JB, Vermeire PA, Buist AS, Thun MJ, et al. Epidemiology and costs of chronic obstructive pulmonary disease. Eur Respir J 2006;27(1):188-207.

4. Cramer JA, Roy A, Burrell A, Fairchild CJ, Fuldeore MJ, Ollendorf DA, Wong PK. Medication compliance and persistence: terminology and definitions. Value Health 2008;11(1):44-47.

5. Ágh T, Mészáros Á. Adherence to therapy in chronic obstructive pulmonary disease. In: Ong KC, editor. Chronic obstructive pulmonary disease-current concepts and practice. Rijeka, Croatia: InTech; 2012:275-290.

6. Bourbeau J, Bartlett SJ. Patient adherence in COPD. Thorax 2008; 63(9):831-838.

7. Regueiro CR, Hamel MB, Davis RB, Desbiens N, Connors AF Jr, Phillips RS. A comparison of generalist and pulmonologist care for patients hospitalized with severe chronic obstructive pulmonary disease: resource intensity, hospital costs, and survival. Am J Med 1998;105(5):366-372.

8. Vestbo J, Anderson JA, Calverley PM, Celli B, Ferguson GT, Jenkins $\mathrm{C}$, et al. Bias due to withdrawal in long-term randomised trials in COPD: evidence from the TORCH study. Clin Respir J 2011; 5(1):44-49.

9. Rutten-van Mölken MP, Oostenbrink JB, Tashkin DP, Burkhart D, Monz BU. Does quality of life of COPD patients as measured by the generic EuroQol five-dimension questionnaire differentiate between COPD severity stages? Chest 2006;130(4):1117-1128.

10. Berger ML, Bingefors K, Hedblom EC, Pashos CL, Torrance GW, editors. Health care cost, quality, and outcomes: ISPOR book of terms. Lawrenceville, New Jersey: ISPOR; 2003;129-131.

11. von Elm E, Altman DG, Egger M, Pocock SJ, Gøtzsche PC, Vandenbroucke JP, STROBE Initiative. The Strengthening the Reporting of Observational Studies in Epidemiology (STROBE) statement: guidelines for reporting observational studies. J Clin Epidemiol 2008; 61(4):344-349.
12. Bosley CM, Corden ZM, Rees PJ, Cochrane GM. Psychological factors associated with use of home nebulized therapy for COPD. Eur Respir J 1996;9(11):2346-2350.

13. Corden ZM, Bosley CM, Rees PJ, Cochrane GM. Home nebulized therapy for patients with COPD: patient compliance with treatment and its relation to quality of life. Chest 1997;112(5):1278-1282.

14. Hesselink AE, van der Windt DA, Penninx BW, Wijnhoven HA, Twisk JW, Bouter LM, van Eijk JT. What predicts change in pulmonary function and quality of life in asthma or COPD? J Asthma 2006;43(7):513-519.

15. Mochizuki H, Nanjo Y, Takahashi H. Better adherence to a transdermal tulobuterol patch than inhaled salmeterol in elderly chronic obstructive pulmonary disease patients. Geriatr Gerontol Int 2013; 13(2):398-404.

16. Turner J, Wright E, Mendella L, Anthonisen N. Predictors of patient adherence to long-term home nebulizer therapy for COPD. The IPPB Study Group. Intermittent positive pressure breathing. Chest 1995; 108(2):394-400.

17. Ágh T, Inotai A, Mészáros Á. Factors associated with medication adherence in patients with chronic obstructive pulmonary disease. Respiration 2011;82(4):328-334

18. Takemura M, Mitsui K, Itotani R, Ishitoko M, Suzuki S, Matsumoto $\mathrm{M}$, et al. Relationships between repeated instruction on inhalation therapy, medication adherence, and health status in chronic obstructive pulmonary disease. Int J Chron Obstruct Pulmon Dis 2011; 6(Can't get issue from record):97-104.

19. Kilcoyne A., O'Connor D., Ambery P. Pharmaceutical Medicine. Oxford: Oxford University Press; 2013:281.

20. Gupta VK, Bahia JS, Maheshwari A, Arora S, Gupta V, Nohria S. To study the attitudes, beliefs and perceptions regarding the use of inhalers among patients of obstructive pulmonary diseases and in the general population in Punjab. J Clin Diagn Res 2011;5(3):434439 .

21. Cleemput I, Kesteloot K, DeGeest S. A review of the literature on the economics of noncompliance. Room for methodological improvement. Health Policy 2002;59(1):65-94.

22. Côté I, Farris K, Feeny D. Is adherence to drug treatment correlated with health-related quality of life? Qual Life Res 2003;12(6):621633.

23. Mikkelsen RL, Middelboe T, Pisinger C, Stage KB. Anxiety and depression in patients with chronic obstructive pulmonary disease (COPD). A review. Nord J Psychiatry 2004;58(1):65-70.

24. Iguchi A, Senjyu H, Hayashi Y, Kanada R, Iwai S, Honda S, et al. Relationship between depression in patients with COPD and the percent of predicted $\mathrm{FEV}_{1}$, BODE index, and health-related quality of life. Respir Care 2013;58(2):334-339.

25. Pickard AS, Yang Y, Lee TA. Comparison of health-related quality of life measures in chronic obstructive pulmonary disease. Health Qual Life Outcomes 2011;9:26.

26. Jones PW. Health status and the spiral of decline. COPD 2009;6(1): 59-63. 